\title{
Giant Hemorrhagic Adrenal Pseudocyst in Pregnancy
}

\author{
${ }^{1}$ Christopher M White, ${ }^{2}$ Harvey Greenberg, ${ }^{3}$ Brian R Davis, ${ }^{4}$ Sanja Kupesic Plavsic
}

\begin{abstract}
Adrenal cysts are a rare diagnosis, particularly in pregnancy. We report the case of a 32-year-old pregnant woman with an adrenal pseudocyst in her 28th week of pregnancy. This represents the 13th case of an adrenal pseudocyst in pregnancy reported in the literature. The patient presented to our facility complaining of abdominal pain, believing she could be in preterm labor. After further evaluation and surgery, she was diagnosed with a left adrenal pseudocyst. In this report, we will not only describe our case but also discuss the relevance of the findings to what is already present in the literature. Our case report is an example of multidisciplinary approach to a pregnant patient with an abdominal/pelvic mass. Inter-professional collaboration allowed successful surgical intervention that resulted in an excellent outcome for the mother and term delivery of child.
\end{abstract}

Keywords: Adrenal pseudocyst, Abdominal pain, Pregnancy, Preterm labor, Ultrasound, Color Doppler ultrasound.

How to cite this article: White CM, Greenberg H, Davis BR, Kupesic Plavsic S. Giant Hemorrhagic Adrenal Pseudocyst in Pregnancy. Donald School J Ultrasound Obstet Gynecol 2014;8(1):105-108.

\section{Source of support: Nil}

Conflict of interest: None

\section{INTRODUCTION}

Adrenal cysts are rare findings and quite foreign to the literature. As of early 2012, there have been less than 100 cases of hemorrhagic pseudocysts reported with the giant variety being even rarer. ${ }^{1}$ Doran wrote in 1908 that Greiselius of Vienna removed the first documented adrenal cyst in $1670 .^{2}$

There are 4 different types of adrenal cysts-parasitic cysts $(7 \%)$, epithelial cysts (9\%), pseudocysts (39\%) and

\footnotetext{
${ }^{1}$ Resident, ${ }^{2}$ Associate Professor, ${ }^{3}$ Assistant Professor ${ }^{4}$ Assistant Dean and Professor

${ }^{1}$ Department of Surgery, University of Texas Southwestern Medical Center, Dallas, Texas, USA

${ }^{2,4}$ Department of Obstetrics and Gynecology, Paul L Foster School of Medicine, Texas Tech University Health Sciences Center at EI Paso, Texas, USA

${ }^{3}$ Department of Surgery, Paul L Foster School of Medicine, Texas Tech University Health Sciences Center at EI Paso, Texas, USA

Corresponding Author: Sanja Kupesic Plavsic, Assistant Academic Dean for Faculty Development, Professor, Department of Obstetrics and Gynecology, Clinical Professor of Radiology, Paul L Foster School of Medicine, Texas Tech University, 4800 Alberta Ave, El Paso, TX 79905, USA Phone: +1 (915)2156505, e-mail: sanja.kupesic@ttuhsc.edu
}

endothelial cysts $(45 \%)$. The latter two are vascular in etiology. The pathogenesis remains somewhat unclear but is thought to be secondary to repeated episodes of trauma, infection or bleeding. ${ }^{3}$ Adrenal cysts fall under the umbrella of adrenal incidentalomas; however, adrenal cysts only comprise $6 \%$ of all worked-up adrenal incidentalomas. ${ }^{4}$

We report the case of a 32-year-old woman in her 28th week of pregnancy that presented with what was originally thought to be an adnexal mass and was taken to the operating room for definitive diagnosis and exploration. Upon definitive diagnosis, confirmation of a giant hemorrhagic adrenal pseudocyst was made, yielding the 13th reported case of a giant hemorrhagic adrenal pseudocyst in pregnancy. ${ }^{5}$

\section{CASE REPORT}

A 32-year-old G6 P3023 in her 28th week of pregnancy with one prenatal visit at 20 weeks in Mexico was admitted to the labor and delivery unit at our facility complaining of abdominal pain. The patient had a past medical history significant for HPV, herpes and chlamydia. She had a past surgical history of cervical cryotherapy secondary to HPV as well as two dilation and curettages secondary to incomplete abortions.

At presentation, she was taking no medications and evaluation for gonorrhea/chlamydia was negative. At our facility she was diagnosed with gestational diabetes. An ultrasound of the abdomen/pelvis was performed to evaluate fetal well-being and revealed a well-delineated $23 \times 17 \times 15 \mathrm{~cm}$ complex abdominal mass that appeared to originate from the left adnexa (Fig. 1). The mass was qualified as multilocular-solid, with no evidence of papillary protrusions. Posterior enhanced through-transmission was seen, signifying the predominant cystic nature of the lesion. Within the mass there were numerous septations measuring from 1 to $10 \mathrm{~mm}$, which contributed to reticular appearance of the mass. Color Doppler showed no flow in these septations and/or solid parts. There was no free fluid in the cul-de-sac. The gynecologic oncology team was consulted and the decision was made to take the patient to the operating room due to the risk that based on morphologic assessment, this mass could be malignant. Because of lack of perfusion on Doppler, adnexal torsion was considered in differential diagnosis. After antenatal corticosteroids were administered, an exploratory laparotomy was performed. After freeing adhesions, the mass was found to be free of any 


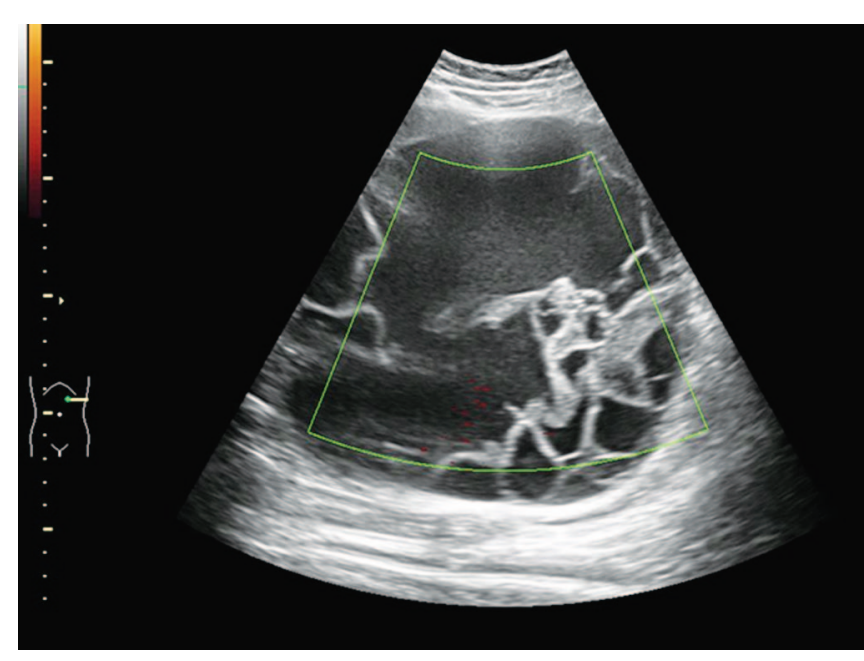

Fig. 1: Power Doppler ultrasound showing complex abdominal mass. Note thickened septations and solid parts



Fig. 2: Intraoperative view of the abdomen with exposed adrenal pseudocyst/mass (M), gravid uterus (U) and spleen (S)

attachments to the pelvic anatomy and appeared to originate from the retroperitoneum. An intraoperative consult was placed for the general surgery team.

The surgeon noted that the mass was adherent to the posterior capsule of the spleen yielding the suspicion that this mass could be originating from the lower pancreas. The lesser sac was explored and the gastrocolic ligament was opened, demonstrating that the mass was originating from another retroperitoneal structure. Further dissection revealed that the lesion was well-encapsulated and full of fluid and originated from the left flank. The mass was also adherent to the diaphragm. This attachment was freed and the base of the tumor was now determined to originate from the left adrenal gland (Fig. 2). The mass was intimately involved with the majority of the adrenal gland so the entire left gland was removed with the mass. The left kidney appeared anatomically normal.

The specimen was sent to pathology for frozen sections and was noted to be $17 \times 15 \times 12.5 \mathrm{~cm}$ and weighed $3 \mathrm{~kg}$. Frozen section demonstrated a distended adrenal

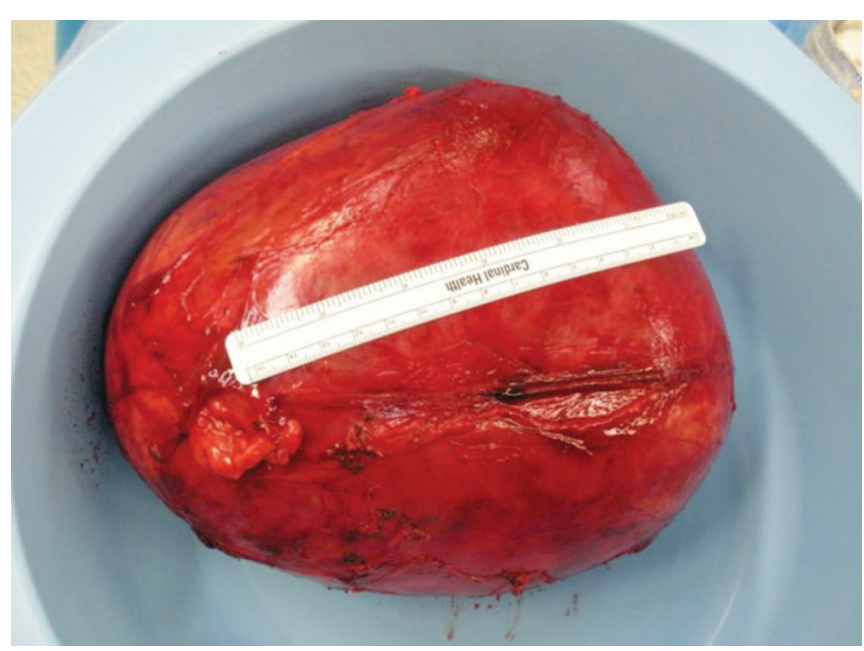

Fig. 3: Left adrenal mass-measuring $17 \times 15 \times 12.5 \mathrm{~cm}$ and weighing $3 \mathrm{~kg}$

gland with an adjacent cystic structure with a cavity filled with hemorrhagic material. No tumor masses or papillary projections were found (Fig. 3).

The patient remained stable throughout the surgery and required a splenorrhaphy for a small tear to the splenic capsule during dissection. Fetal heart monitoring throughout the case remained within normal limits. A 19-French Jackson Pratt drain was left in place.

The patient was transferred to the ICU for monitoring and to follow her hemoglobin/hematocrit levels. She remained stable postoperatively and suffered no further complications of her procedure. She had no evidence of adrenal insufficiency and was discharged on postoperative day 7 . She delivered an anatomically normal, healthy baby 3 months following surgery.

Histopathologic examination of the specimens submitted failed to identify adrenal neoplasms but did reveal numerous hemosiderin laden macrophages and a single layer of fibroblasts encompassing the cyst. The cyst contained blood and partially organized fibrin. The diagnosis of a giant hemorrhagic adrenal pseudocyst was confirmed.

\section{DISCUSSION}

Adrenal pseudocysts are an exceedingly rare finding and this case represents the rarity of this finding, particularly in pregnancy. The incidence of adrenal cysts has been steadily increasing and this is thought to be due to the increased availability and use of CT scans. ${ }^{6}$

The majority of all adrenal pseudocysts are benign (93\%). The risk of malignancy is positively correlated with the size of the pseudocyst, particularly if the pseudocyst is greater than $6 \mathrm{~cm}$ in its greatest dimenion. ${ }^{6}$

Adrenal pseudocysts are typically asymptomatic; however, if symptomatic the most common presentation is 
Table 1: Demographics and clinical data of the 13 pregnant patients with adrenal pseudocysts ${ }^{5,17-26}$

\begin{tabular}{|c|c|c|c|c|c|c|}
\hline First author, Year ref & $\begin{array}{l}\text { Age } \\
\text { (yrs) }\end{array}$ & $\begin{array}{l}\text { Gestational } \\
\text { age }\end{array}$ & $\begin{array}{l}\text { Size }(\mathrm{cm}) \text { and/or } \\
\text { weight }(\mathrm{gm})\end{array}$ & Side and type & Treatment & $\begin{array}{l}\text { Pregnancy } \\
\text { outcome }\end{array}$ \\
\hline Karaman, $2011^{5}$ & 40 & 20 weeks & $2 \times 15 \mathrm{~cm}$ & $\begin{array}{l}\text { Left adrenal } \\
\text { (hemorrhagic) }\end{array}$ & $\begin{array}{l}\text { Complete cystectomy, left } \\
\text { adrenalectomy }\end{array}$ & $\begin{array}{l}\text { Vaginal term } \\
\text { delivery }\end{array}$ \\
\hline Thomson, $1966^{18}$ & 23 & 8 weeks & $20 \times 12 \mathrm{~cm}$ & $\begin{array}{l}\text { Right adrenal } \\
\text { (hemorrhagic) }\end{array}$ & $\begin{array}{l}\text { Complete cystectomy, right } \\
\text { adrenalectomy }\end{array}$ & $\begin{array}{l}\text { Vaginal term } \\
\text { delivery }\end{array}$ \\
\hline Osborne, $1974^{19}$ & 28 & 17 weeks & $\begin{array}{l}15 \mathrm{~cm} \text { (mean } \\
\text { diameter) }\end{array}$ & $\begin{array}{l}\text { Right adrenal } \\
\text { (hemorrhagic) }\end{array}$ & $\begin{array}{l}\text { Complete cystectomy, } \\
\text { right adrenalectomy, right } \\
\text { nephrectomy }\end{array}$ & Unknown \\
\hline Costandi, $1975^{20}$ & 32 & $\begin{array}{l}\text { 2nd } \\
\text { trimester }\end{array}$ & $\begin{array}{l}12 \mathrm{~cm} \text { (mean } \\
\text { diameter), } 360 \mathrm{gm}\end{array}$ & $\begin{array}{l}\text { Right adrenal } \\
\text { (non-hemorrhagic) }\end{array}$ & $\begin{array}{l}\text { Complete cystectomy, } \\
\text { right adrenalectomy, right } \\
\text { nephrectomy }\end{array}$ & Unknown \\
\hline Rao, $1976^{21}$ & 27 & 12 weeks & $11,500 \mathrm{gm}$ & $\begin{array}{l}\text { Right adrenal } \\
\text { (hemorrhagic) }\end{array}$ & $\begin{array}{l}\text { First surgery: exploratory } \\
\text { laparotomy, } \\
\text { 2nd surgery: complete } \\
\text { cystectomy }\end{array}$ & $\begin{array}{l}\text { Vaginal term } \\
\text { delivery }\end{array}$ \\
\hline Uretzky, $1978^{22}$ & 29 & 8 weeks & $\begin{array}{l}20 \mathrm{~cm} \text { (mean } \\
\text { diameter) }\end{array}$ & $\begin{array}{l}\text { Right adrenal } \\
\text { (non-hemorrhagic) }\end{array}$ & $\begin{array}{l}\text { Complete cystectomy, } \\
\text { partial right adrenalectomy }\end{array}$ & $\begin{array}{l}\text { Elective } \\
\text { termination }\end{array}$ \\
\hline Bartlett, $1995^{23}$ & 33 & 14 weeks & $15 \times 11 \mathrm{~cm}, 365 \mathrm{gm}$ & $\begin{array}{l}\text { Right adrenal } \\
\text { (hemorrhagic) }\end{array}$ & $\begin{array}{l}\text { Unsuccessful percutaneous } \\
\text { drainage followed by } \\
\text { complete cystectomy with } \\
\text { right adrenalectomy }\end{array}$ & $\begin{array}{l}\text { Vaginal term } \\
\text { delivery }\end{array}$ \\
\hline Trauffer, $1996^{24}$ & 33 & 14 weeks & $20 \times 11 \times 14 \mathrm{~cm}$ & $\begin{array}{l}\text { Right adrenal } \\
\text { (hemorrhagic) }\end{array}$ & $\begin{array}{l}\text { Unsuccessful percutaneous } \\
\text { drainage followed by } \\
\text { complete cystectomy with } \\
\text { right adrenalectomy }\end{array}$ & $\begin{array}{l}\text { Vaginal term } \\
\text { delivery }\end{array}$ \\
\hline Tait, $1997^{25}$ & 28 & 26 weeks & $20 \times 40 \mathrm{~cm}$ & $\begin{array}{l}\text { Right adrenal } \\
\text { (non-hemorrhagic) }\end{array}$ & Complete cystectomy & $\begin{array}{l}\text { Preterm } \\
\text { vaginal } \\
\text { delivery }\end{array}$ \\
\hline $\begin{array}{l}\text { Papaziogas, } \\
2006^{11}\end{array}$ & 27 & 28 weeks & $11 \times 12 \mathrm{~cm}$ & $\begin{array}{l}\text { Left adrenal } \\
\text { (hemorrhagic) }\end{array}$ & $\begin{array}{l}\text { First surgery: exploratory } \\
\text { laparotomy, 2nd surgery: } \\
\text { complete cystectomy with } \\
\text { left adrenalectomy }\end{array}$ & $\begin{array}{l}\text { Cesarean } \\
\text { section at } \\
\text { term }\end{array}$ \\
\hline Sivasankar, $2006^{26}$ & 20 & 8 weeks & $\begin{array}{l}20 \mathrm{~cm} \text { (mean } \\
\text { diameter) }\end{array}$ & $\begin{array}{l}\text { Right adrenal } \\
\text { (hemorrhagic) }\end{array}$ & Complete cystectomy & $\begin{array}{l}\text { Elective } \\
\text { termination }\end{array}$ \\
\hline Sivasankar, $2006^{26}$ & 24 & 20 weeks & $14 \times 16 \mathrm{~cm}$ & $\begin{array}{l}\text { Right adrenal } \\
\text { (hemorrhagic) }\end{array}$ & Complete cystectomy & $\begin{array}{l}\text { Preterm } \\
\text { vaginal } \\
\text { delivery }\end{array}$ \\
\hline Present case & 32 & 28 weeks & $\begin{array}{l}12.5 \times 15 \times 17 \\
\mathrm{~cm}, 3,000 \mathrm{gm}\end{array}$ & $\begin{array}{l}\text { Left adrenal } \\
\text { (hemorrhagic) }\end{array}$ & $\begin{array}{l}\text { Complete cystectomy, } \\
\text { left adrenalectomy; } \\
\text { splenorrhaphy }\end{array}$ & $\begin{array}{l}\text { Vaginal term } \\
\text { delivery }\end{array}$ \\
\hline
\end{tabular}

abdominal or flank pain due to compression of surrounding structures. Other symptoms include shortness of breath or fever/chills. The most common sign is a palpable mass on exam or sensation of abdominal fullness. Other documented signs include hypertension, shock or superimposed infection. ${ }^{3,7,8}$ Adrenal pseudocysts causing signs of adrenal hypo- or hyperfunction are very uncommon, however. ${ }^{4}$ There have been other documented cases in pregnancy of adrenal pseudocysts presenting with an acute abdomen and this is thought to be secondary to hemorrhage occurring into the cyst. ${ }^{7}$

In the obstetric population, the diagnosis of an adrenal pseudocyst is rarely established preoperatively and the provisional diagnoses have included ectopic pregnancy with massive hemorrhage, ovarian vein syndrome, gallbladder hydrops, ovarian cyst undergoing intermittent torsion, cyst of the right lobe of the liver, cyst arising from the right adnexa, bleeding hepatic adenoma or retroperitoneal cyst, bleeding liver tumor and a mesenteric cyst. ${ }^{8.9}$

For diagnosis of adrenal pseudocysts, the gold standard remains computed tomography, although ultrasound and MRI are also utilized. MRI has high sensitivity for even small masses and is superior for tissue characterization. ${ }^{6}$

In our pregnant patient the clinical features included pelvic pain and abdominal mass. Complex appearance of the lesion, mixed echogenicity, thick septations and solid parts originating from disintegrated blood clot gave an appearance of ovarian neoplasm. However, color Doppler revealed no flow in these septations and solid parts, because fibrin strands and blood clot do not contain blood vessels. 
Acute onset of abdominal pain may mimic other gynecologic conditions such as adnexal torsion. Absence of ovarian blood flow on Doppler sonography is a good predictor of adnexal torsion, which was considered in the differential diagnosis. ${ }^{10}$

Treatment of adrenal pseudocysts remains surgical removal for all tumors larger than $5 \mathrm{~cm}$, if there is any suspicion of malignancy or if the tumor is hormonally active. ${ }^{11-16}$ There is also evidence to recommend surgery if the tumor is at least $4 \mathrm{~cm}$ in size. If the tumor is less than $4 \mathrm{~cm}$ in size, patients should undergo a repeat CT scan in 3 months and be monitored for at least 18 months. ${ }^{6}$

Table 1 illustrates demographics and clinical data of the 13 pregnant patients with adrenal cysts reported in the literature. ${ }^{5,10,18-26}$ Although these tumors are exceedingly rare in pregnancy, a multidisciplinary approach allowed successful surgical intervention that resulted in an excellent outcome for the mother and term delivery of child. A high index of suspicion for retroperitoneal tumors and adrenal pseudocysts should be present in every patient evaluated for adnexal masses, especially during pregnancy.

\section{REFERENCES}

1. Gupta V, Gupta P, Agarwal P. Gastrointestinal: giant hemorrhagic adrenal pseudocyst. J Gastroenterology and Hepatology 2012;27:183.

2. Doran AHG. Suprarenal tumor of the adrenal body successfully removed by operation. BMJ 1908;1(2478):1558-1563.

3. Carvounis E. Vascular adrenal cysts a brief review of the literature. Arch Pathol Lab Med 2006;130:1722-1724.

4. Aloraifi F, O`Brien G, Broe P. Giant adrenal pseudocyst treated laparoscopically: case report and review of the literature. Open Surg J 2008;2:39-42.

5. Karaman K, Bostanci EB, et al. Giant hemorrhagic adrenal pseudocyst in a primiparous pregnancy: report of a case. Surg Today 2011;41:153-158.

6. Kim BS, Joo SH, Choi SI. Laparoscopic resection of an adrenal pseudocyst mimicking a retroperitoneal mucinous cystic neoplasm. World J Gastroenterol 2009;15(23):2923-2926.

7. Kar M, Pucci E, Brody F. Laparoscopic resection of an adrenal pseudocyst. J Laparoendosc Adv Surg Tech 2006;16(5):478-481.

8. Neri LM, Nance FC. Management of adrenal cysts. Am Surg 1999;65:151-163.
9. Demir A, Tanidir Y, Kaya H. A giant adrenal pseudocystcase report and review of the literature. Int Urol Nephrol 2006;38(1):167-169.

10. Kupesic S, Plavsic BM. Adnexal torsion: color Doppler and threedimensional ultrasound. Abdominal Imaging 2010;35:602-606.

11. Papaziogas B, Katsikas B, Psaralexis K. Adrenal pseudocyst presenting as acute abdomen during pregnancy. Acta Chir Belg 2006;106:722-725.

12. Yip L, Tublin ME, Falcone JA. The adrenal mass: correlation of histopathology with imaging. Ann Surg Oncol 2010;17:846-852.

13. Wedmid A, Palese M. Diagnosis and treatment of the adrenal cyst. Curr Urol Rep 2010;11(1):44-50.

14. Kasperlik-Zeluska AA, Rosłonowska E, Słowinska-Srzednicka J. Incidentally discovered adrenal mass (incidentaloma): investigation and management of 208 patients. Clin Endocrinol 1997;46(1):29-37.

15. Ujam AB, Peters CJ, Tadrous PJ, Webster JJ, Steer K, Isla AM. Adrenal pseudocyst: diagnosis and laproscopic management- $-\mathrm{a}$ case report. Int J Surg Case Rep 2011;2(8):306-308.

16. Herrera MF, Grant CS, van Heerden. Incidentally discovered adrenal tumors: an institutional perspective. Surgery 1991;110(December (6)):1014-1021.

17. Rao A, Majmudar B, Bumpers H. Giant adrenal pseudocyst. Int J Surg Case Rep 2011;2(8):306-308.

18. Thompson AG, Jacobson SA. Pseudocyst of adrenal gland. Can Med Assoc J 1966;94:90-91.

19. Osborne AH. Three cases of retroperitoneal cyst with discussion of X-ray diagnosis by excretory urogram and review of literature. J Urol 1974;112:541-545.

20. Costandi YT, Inaba Y, Kerr A, Wendel RG, Henning DC, Evans AT. Calcified adrenal cysts. Urology 1975;5:777-779.

21. Rao MS, Bhagwat AG, Vaidyanathan S. Massive enlargement of adrenal cysts during pregnancy. S Afr J Surg 1976;14:13-16.

22. Uretzky G, Freund H, Charuzi I, Luttwak EM. Cysts of the adrenal gland. Eur Urol 1978;4:97-99.

23. Bartlett DL, Cohen A, Huttner R, Torosian MH. Adrenal pseudocyst in pregnancy. Surgery 1995;118:567-570.

24. Trauffer PM, Malee MP. Adrenal pseudocyst in pregnancy. A case report. J Reprod Med 1996;41:195-197.

25. Tait DL, Williams J, Sandstad J, Lucci JA 3rd. Benign adrenal cyst presenting in a pregnant patient. Am J Perinatol 1997;14: 461-464.

26. Sivasankar A, Jeswanth S, Johnson MA, Ravichandran P, Rajendran S, Kannan DG, et al. Acute hemorrhage into adrenal pseudocyst presenting with shock: diagnostic dilemmas - report of three cases and review of the literature. Sci World J 2006;6: 2381-2387. 